\title{
Functional properties of electrolytic alloys of Cobalt with Molybdenum and Zirconium
}

\author{
M.V.Ved', M.A.Koziar, N.D.Sakhnenko, M.A.Slavkova \\ National Technical University "Kharkiv Polytechnic of Institute", \\ 21 Frunze Str., 61002 Kharkiv, Ukraine
}

\section{Received February 3, 2016}

Functional electrolytic alloy coatings of Co-Mo and Co-Mo-Zr were deposited on substrates of 3 type steel from polyligand citrate-pyrophosphate bath using pulsed current. It is shown the alloying components content, their distribution on the surface, morphology and topography of the coatings are depended on the electrolysis energetic parameters. It is confirmed that the functional properties of the binary and ternary electrolytic cobalt alloys (corrosion resistance, catalytic activity both in hydrogen evolution and carbon II oxide oxidation) are predetermined by material composition, morphology and surface relief. Chemical stability of Co-Mo, and Co-Mo-Zr systems in aggressive media is conditional on increased susceptibility to passivity when the molybdenum and zirconium are incorporated in the coating, and the stability is a prerequisite of their use for corrosion protection. The high level of catalytic properties of Co-Mo, and Co-Mo-Zr coatings associated with different affinities for alloying metals to oxygen as well as verification of hydrogen evolution mechanism allows to recommend them for platinum metals replacement in the heterogeneous catalysis.

Keywords: cobalt alloys, alloying with molybdenum and zirconium, electrochemical synthesis, functional properties, pulse electrolysis, polyligand electrolyte, corrosion resistance, catalytic properties, synergetic effect.

\footnotetext{
Функциональные электролитические покрытия сплавами Co-Mo и Co-Mo-Zr получены из полилигандного цитратно-пирофосфатного электролита в импульсном режиме на подложках из стали 3. Показано, что содержание легирующих компонентов, их распределение по поверхности, морфология и топография покрытий зависят от энергетических параметров электролиза. Подтверждено, что функциональные свойства бинарного и тернарного электролитических сплавов кобальта (коррозионная стойкость, каталитическая активность в реакциях выделения водорода и окисления оксида углерода II) предопределяются составом материала, морфологией и рельефом поверхности. Химическая стойкость систем Co-Mo и Co-Mo-Zr в агрессивных средах обусловлена повышением склонности к пассивации при включении молибдена и циркония в состав покрытий и является предпосылкой их использования для защиты от коррозии. Высокий уровень каталитических свойств Со-Мо и Сo-Mo-Zr связан с различным сродством сплавообразующих металлов к кислороду и верификацией механизма выделения водорода и позволяет рекомендовать их для замены платиновых металлов в гетерогенном катализе.
}

Функціональні властивості електролітичних сплавів кобальту з молібденом і цирконієм. М.В.Ведь, М.А.Козяр, М.Д.Сахненко, М.О.Славкова.

Функціональні електролітичні покриття сплавами Co-Mo i Co-Mo-Zr одержано $з$ полілігандного цитратно-пірофосфатного електроліту в імпульсному режимі на підкладках зі сталі 3. Показано, що вміст легуючих компонентів, їх розподіл відовж поверхні, морфологія і топографія покриттів залежать від енергетичних параметрів електролізу. Встановлено, що функціональні властивості бінарних і тернарних сплавів кобальту 
(корозійна стійкість, каталітична активність у реакціях виділення водню і окиснення оксиду карбону II) обумовлені складом матеріалу, морфологією та рельєфом поверхні. Хімічна стійкість систем Co-Mo i Co-Mo-Zr в агресивних середовищах, обумовлена підвищенням схильності до пасивації при включенні молібдену і цирконію до складу покриттів, є передумовою їх використання для захисту від корозії. Високий рівень каталітичних властивостей Co-Mo i Co-Mo-Zr пов'язаний із різною спорідненістю сплавотвірних металів до оксигену й верифікацією механізму виділення водню, дозволяє рекомендувати ї для заміни платинових металів у гетерогенному каталізі.

\section{Introduction}

Development of the high technology industries (refining, chemical, pharmaceutical), creation of advanced chemical power sources, as well as ensuring the environmental safety of vehicles and industrial plants is impossible without effective catalysts for a wide range of processes. Therefore it becomes extremely relevant problem of synthesis of thin layer catalytic materials which are free of precious metals platinum and palladium families. Taking into account the accumulated experience, we can say that as the most effective for heterogeneous catalysis should be considered the mixed oxide systems based on polyvalent transition metals $[1,2]$ or the mixtures of such metals [3,4]. In despite of the variety of applications, in some cases - for electrode (cathodic) materials in synthesis of hydrogen, hydrogenation processes, and others preference should be given for polymetallic systems.

For thin-layered catalysts synthesis it is appropriate to use electrochemical techniques that allow obtaining multicomponent coatings of various thicknesses with a good adhesion to the substrate, as well as provide a flexible management of materials structure and therefore their properties.

Selection of components for electrolytic alloys is based on an analysis of physicochemical properties of the selected metals, their thermodynamic stability, affinity for hydrogen, oxygen and some other elements. There is now sufficient demand for cobaltbased material with dopants of refractory metals (tungsten and molybdenum) [5,6]. This choice is primarily due to the high acceptor capacity of these metals and their propensity for passivity and formation of polyvalent oxides, which determines the catalytic activity, mechanical strength and corrosion resistance. Previously the authors of [7] marked synergistic effect both of the catalytic activity and the microhardness of binary $\mathrm{Co}(\mathrm{Ni})-\mathrm{W}$ alloys. At the same time, in our opinion, level of functional properties of the binary coatings can be significantly increased by doping them with $d^{2}$ - metals, in particular zirconium. It should be noted that the metals of $4 \mathrm{~B}$ subgroup are unique due to combination of lightness and corrosion resistance, especially in acid environments. They are also characterized by photocatalytic properties, have a high affinity for oxygen, thus their incorporation into the polymetallic systems looks attractive.

Unfortunately, it is known that titanium and zirconium, the standard potentials of which are $-1.53 \mathrm{~V}$ and $-1.21 \mathrm{~V}$, respectively, are not reduced to metallic state from the aqueous solutions. Nevertheless, as it has been shown in [8], the electrolytic coating of Co-Mo containing up to 4 wt.\% zirconium was deposited from polyligand electrolyte.

The goal of this study is to examine the effect of composition and morphology of the alloy coatings consisted of cobalt with molybdenum and zirconium on their catalytic activity in heterogeneous red-ox processes and corrosion resistance.

\section{Experimental}

The coatings were formed on substrates of 3 type steel, surface pretreatment of which was performed by the standard technique.

The coatings were deposited from the bath composition, mol $\cdot \mathrm{dm}^{-3}$ : $\mathrm{CoSO}_{4} \cdot 7 \mathrm{H}_{2} \mathrm{O}-$ $0.1-0.15 ; \mathrm{Na}_{2} \mathrm{MoO} 4-0.02-0.06 ; \mathrm{Zr}\left(\mathrm{SO}_{4}\right)_{2}$ - 0.05; $\mathrm{Na}_{3} \mathrm{C}_{6} \mathrm{H}_{5} \mathrm{O}_{7} \cdot 2 \mathrm{H}_{2} \mathrm{O}\left(\mathrm{Na}_{3} \mathrm{Cit}\right)-0.2$; $\mathrm{K}_{4} \mathrm{P}_{2} \mathrm{O}_{7}-0.1$. Acidity of the electrolyte was adjusted with $\mathrm{NaOH}$ or $\mathrm{H}_{2} \mathrm{SO}_{4}$ and was maintained in the range of $\mathrm{pH}$ 8-9. Working solutions were prepared from chemicals of reagent grade dissolved in a small amount of distilled water following by solution mixture in a certain sequence, based on the ionic equilibrium study results [8].

The coatings were formed with unipolar pulse current with amplitude of 4$10 \mathrm{~A} \cdot \mathrm{dm}^{-2}$ in the frequency $f$ range of $19-$ $910 \mathrm{~Hz}$, at pulse time $t_{\text {on }} 2 \cdot 10^{-3}-1 \cdot 10^{-2} \mathrm{sec}$ and pause duration $t_{\text {off }} 2 \cdot\left(10^{-3}-10^{-2}\right) \mathrm{sec}$; duty cycle was $2-20$. As anodes there were served cobalt plates or steel 3 plates coated with the cobalt-molybdenum alloy of thickness being $10 \mu \mathrm{m}$, which obtained as in [5, 8]. 


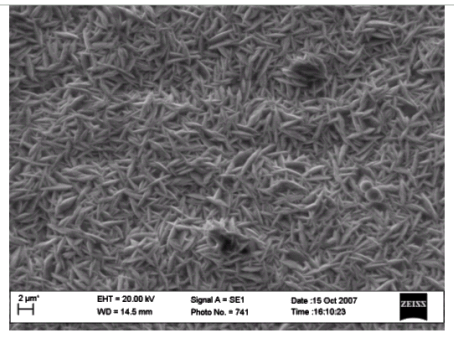

a

Co- 99.7

Mo -0.3

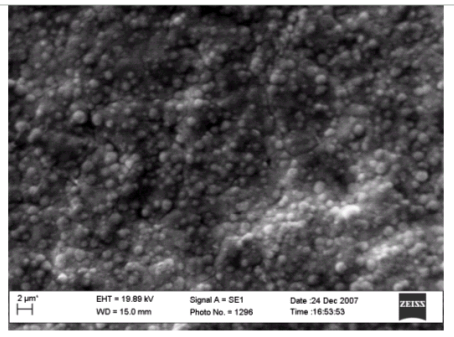

b

Co- 87.1

Mo -12.9

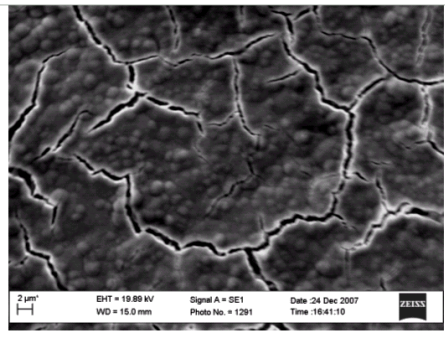

C

Co -90.5

Mo -9.5

Fig. 1. Morphology, structure and composition (at. \%) of coatings Co (a) and Co-Mo deposited with current density $3(\mathrm{a}, \mathrm{b})$ and 8 (c) $\mathrm{A} / \mathrm{dm}^{-2}, t_{\text {on }} / t_{\text {off }}=2 / 10 \mathrm{msec}, T=20-25^{\circ} \mathrm{C}$. Magnification $\times 2000$.

The pulsed electrolysis was performed at the laboratory complex, which includes potentiostat PI-50-1.1 with PR-8 programming unit and computer equipped with a card for automatic on-line data registration with a specially designed program to digitize the measurement results.

As reference electrode it was served EVL-1M1 electrode connected to the working cell via electrolytic bridge filled with Ceylon gelatin and saturated $\mathrm{KNO}_{3}$ solution. All potentials in the paper are given relative to the standard hydrogen electrode.

Chemical composition of the coatings was examined with X-ray photoelectron spectroscopy using energy dispersive spectrometer INCA Energy 350 and with X-ray fluorescence method using a portable spectrometer "SPRUT", the absolute error of components did not exceed 1 wt.\%.

Surface morphology was evaluated from the images obtained using a scanning electron microscope (SEM) ZEISS EVO 40XVP registering secondary electrons (BSE) during scanning the patterns by electron beam.

Phase composition of the coatings was studied with X-ray structural analysis performed with DRON-2.0 diffraction meter in the emission of iron anode. Diffractograms were recorded in discrete mode by $0.1^{\circ}$ with exposure at each point -20 .

Corrosion tests were carried out in model media of different $\mathrm{pH}: 3 \%$ sodium chloride solution ( $\mathrm{pH} 7$ ) and $1 \mathrm{M}$ solution of sodium sulfate at $\mathrm{pH} 3$ and 11 . The coatings rate corrosion of was determined by polarization resistance technique analyzing cathodic and anodic polarization dependences in semilogarithmic coordinates [9]. The corrosion resistance of the coatings was evaluated with corrosion current density $i_{c o r}$ and corrosion deep index $k_{h}\left(\mathrm{~mm} \cdot \mathrm{year}^{-1}\right)$ calculated as

$$
k_{h}=8.76 \cdot k_{e} \cdot i_{c o r} / \rho,
$$

where $k_{e}$ - electrochemical equivalent of alloy, $\mathrm{kg} \cdot \mathrm{C}^{-1}$; $i_{\text {cor }}$ - corrosion current density, A.m ${ }^{-2} ; \rho-$ alloy density, $\mathrm{kg} \cdot \mathrm{m}^{-3}$.

Electrochemical equivalent $k_{e}$ and density $\rho$ of the alloys were determined considering their quantitative composition [10].

To investigate the catalytic properties of the coatings it was chosen a model reaction of hydrogen electrochemical evolution from the media with composition similar for the corrosion tests. The hydrogen exchange current density $i_{\mathrm{H}}^{0}$ is utilized as criteria of electrocatalytic activity and efficiency since this parameter is independent of the electrode potential. The Tafel coefficients $a$ and $b$ allow to judge about mechanism of $\mathrm{H}_{2}$ evolution at the varying cathodic materials. Experimentally $i_{\mathrm{H}}^{0}$ was determined as the point of intersection of the linear portions of the polarization dependences in the Tafel coordinates within displacement 200$300 \mathrm{NmV}$ from steady-state potential, coefficient $b$ - from the angle of linear cathodic plot $\lg i-\Delta E$, and $a-$ as the segment on the ordinate axis at zero polarization [10].

The testing of the covers' catalytic properties in carbon (II) oxide oxidation reaction was also carried out in a tubular flow reactor fabricated from quartz glass with the coaxially situated heating element. Initial mixture of CO (1 vol. \%) and air was supplied to the reactor inlet at a rate of $0.025 \mathrm{dm}^{3} \cdot \mathrm{min}^{-1}$. The reactor temperature was increased gradually from 20 to $420^{\circ} \mathrm{C}$. Content of $\mathrm{CO}$ in the mixture at the reactor outlet was analyzed using the indicator-analyzer "Dozor" and the conversion index $\mathrm{X}(\mathrm{CO})$ was calculated as reported in [11]. 


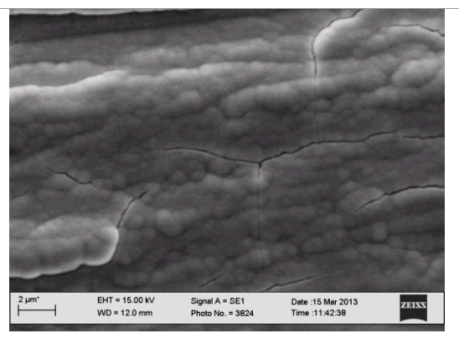

a

$$
\begin{gathered}
\mathrm{Co}-75.4 \\
\mathrm{Mo}-21.4 \\
\mathrm{Zr}-3.2
\end{gathered}
$$

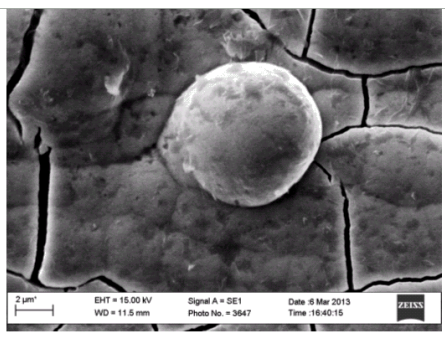

b

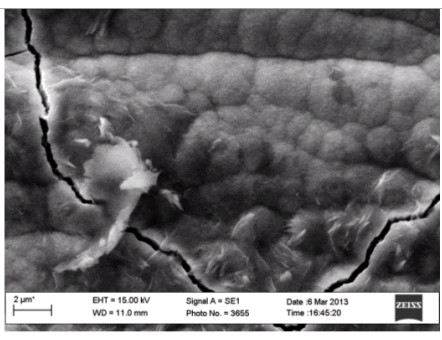

C

$$
\begin{array}{c|c}
\mathrm{Co}-79.1 & \mathrm{Co}-86.3 \\
\mathrm{Mo}-18.5 & \mathrm{Mo}-10.3 \\
\mathrm{Zr}-2.4 & \mathrm{Zr}-3.4
\end{array}
$$

Fig. 2. Morphology, structure and composition (at. \%) of coatings Co-Mo-Zr deposited with current density 3 (a) and $8(\mathrm{~b}, \mathrm{c}) \mathrm{A} \cdot \mathrm{dm}^{-2}, t_{\text {on }} / t_{\text {off }}=2 / 10 \mathrm{msec}, T^{\circ} \mathrm{C}=20-25(\mathrm{a}, \mathrm{b}) 50$ (c) . Magnification $\times 5000$.

\section{Results and discussion}

Surface topography of the binary Co-Mo coatings produced by the pulsed mode from citrate-pyrophosphate electrolyte differs from the crystalline lamellar-needled structure of the cobalt coatings (Fig. 1a) deposited from the citrate electrolyte [6,12]. Doping cobalt by molybdenum promotes formation of globular amorphous surface (Fig. $1 b)$, and it appears refractory metal to be the amorphous-forming agent. The elevating in current density leads to decrease in the molybdenum content and cracking of deposits due to growth of internal stresses (Fig. 1c).

Results of the studies showed the possibility of deposition of ternary Co-Mo-Zr alloy using the pulsed electrolysis (Fig. 2), which in the galvanostatic mode can not be obtained [8]. The composition, morphology and surface topography of the coatings depend not only on the ratio of the alloying components in the electrolyte but, more importantly - from the energy parameters of electrolysis (current density and temperature) that allowing you to flexibly manage the quality and properties of the materials.

Composition analysis of the binary and ternary coatings revealed that besides the main components (Co, Mo and $\mathrm{Zr}$ ) they contain some oxygen and with raising temperature the content of nonmetallic inclusions increases. Such phenomenon is explained by the intensification of the $\mathrm{Co}(\mathrm{II})$ and $\mathrm{Zr}(\mathrm{IV})$ hydrolysis at elevated temperatures, which

\begin{tabular}{|c|c|c|c|}
\hline \multirow{2}{*}{$\begin{array}{l}\text { Corrosion } \\
\text { medium pH }\end{array}$} & \multirow{2}{*}{$\begin{array}{c}\text { Corrosion } \\
\text { parameters }\end{array}$} & \multicolumn{2}{|c|}{ Electrolytic alloys } \\
\hline & & Co-Mo & Co-Mo-Zr \\
\hline \multirow[t]{3}{*}{3} & $i_{\text {cor }}, \mathrm{A} / \mathrm{cm}^{2}$ & $2 \cdot 10^{-4}$ & $3 \cdot 10^{-5}$ \\
\hline & $E_{c o r}, \mathrm{~B}$ & -0.42 & -0.46 \\
\hline & $\begin{array}{c}k_{h}, \\
\mathrm{~mm} / \text { year }\end{array}$ & $2.3 \cdot 10^{-3}$ & $3.1 \cdot 10^{-4}$ \\
\hline \multirow{3}{*}{$\begin{array}{c}7(3 \% \\
\mathrm{NaCl})\end{array}$} & $i_{\text {cor }}, \mathrm{A} / \mathrm{cm}^{2}$ & $2.5 \cdot 10^{-4}$ & $2.1 \cdot 10^{-5}$ \\
\hline & $E_{c o r}, \mathrm{~B}$ & -0.2 & -0.5 \\
\hline & $\begin{array}{c}k_{h}, \\
\mathrm{~mm} / \text { year }\end{array}$ & $2.9 \cdot 10^{-3}$ & $2.2 \cdot 10^{-4}$ \\
\hline \multirow[t]{3}{*}{11} & $i_{\text {cor }}, \mathrm{A} / \mathrm{cm}^{2}$ & $8 \cdot 10^{-5}$ & $3 \cdot 10^{-5}$ \\
\hline & $E_{c o r}, \mathrm{~B}$ & -0.43 & -0.47 \\
\hline & $\begin{array}{c}k_{h}, \\
\mathrm{~mm} / \text { year }\end{array}$ & $9.3 \cdot 10^{-4}$ & $3.1 \cdot 10^{-4}$ \\
\hline
\end{tabular}
leads to formation oxo- and hydroxyl compounds of the alloying metals and their integration in the deposit [13]. In general, the presence of oxygen and carbon in the coating is associated with partial oxidation of the surface or with the adsorption of carbon
Table 1. Corrosion parameters of electrolytic alloys in different media

(IV) oxide from the air. Increasing the amplitude of the current density does not lead to appreciable growth of the content of nonmetallic impurities in the surface layers.

The energy parameters affect the ratio of the base (Co) and the alloying (Mo, Zr) components in the coating. Increasing in the current density and temperature promotes the content of cobalt by decreasing atomic fraction of molybdenum, while the concentration of zirconium is practically unchanged within experimental error. At the same time, morphology and surface topography is transformed from the amorphous uniformly globular grains with an average size of $100 \mathrm{~nm}$ obtained by the current amplitude of $3 \mathrm{~A} \cdot \mathrm{dm}^{-2}$ (Fig. 2a) up to the large-globular for $i=8 \mathrm{~A} \cdot \mathrm{dm}^{-2}$ (Fig. 2b). 


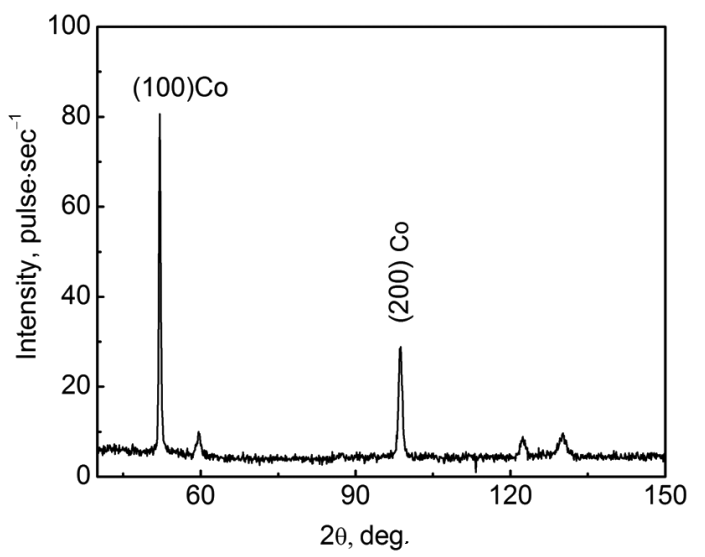

Fig. 3. X-ray pattern for Co-Mo coating.

Simultaneously the level of internal stresses in the coating increases which leads to cracks but the temperature raising reduces the tension and number of defects and needled-lamellar crystalline structure of cobalt is manifested (Fig. 2c) due to significant increase in its atomic fraction.

The synthesized electrolytic coatings Co-Mo and Co-Mo-Zr represent substitutional solid solutions based on cobalt as follows from the X-ray diffraction analysis (Fig. 3). No other phases including intermetallic compounds were not found in the coatings' structure even after 3-hour annealing the coated sample on air at temperature of $600^{\circ} \mathrm{C}$.

Corrosion of the binary and ternary electrolytic coatings proceeds predominantly with hydrogen depolarization in the acidic medium (Fig. 4), and in the neutral and alkaline ones under oxygen action. Corrosion potential of the coatings alloyed with zirconium shifts in the negative direction in all environments (Fig. 4, 5, Table 1) that agrees completely with the thermodynamic characteristics of zirconium. At the same time, the corrosion rate of the ternary alloy in the acidic and neutral chloride-containing environments declines by almost an order of magnitude compared with the binary system (Table 1). It can be explained by increased tendency to passivity of the zirconium-containing material as can be seen from corrosion diagrams (Fig. 4) and geometry of anodic polarization dependences (Fig. 5). Also the ternary alloy increases resistance to pitting corrosion initiated with chloride ions. All mentioned above is experimental confirmation of the working hypothesis that underlies the synthesis of the alloys.

The difference in corrosion rates of Co-Mo and Co-Mo- $\mathrm{Cr}$ coatings in the alkaline environment is not as great due to acidic nature

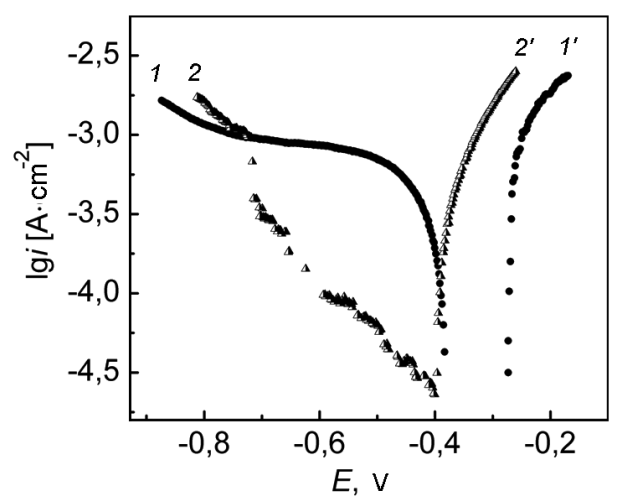

Fig. 4. Corrosion diagrams for coatings Co-Mo (1) and Co-Mo-Zr (2) in $1 \mathrm{M} \mathrm{Na}_{2} \mathrm{SO}_{4}$ with $\mathrm{pH}$ 3 : cathodic plots $(1,2)$; anodic plots $\left(1^{\prime}, 2^{\prime}\right)$.

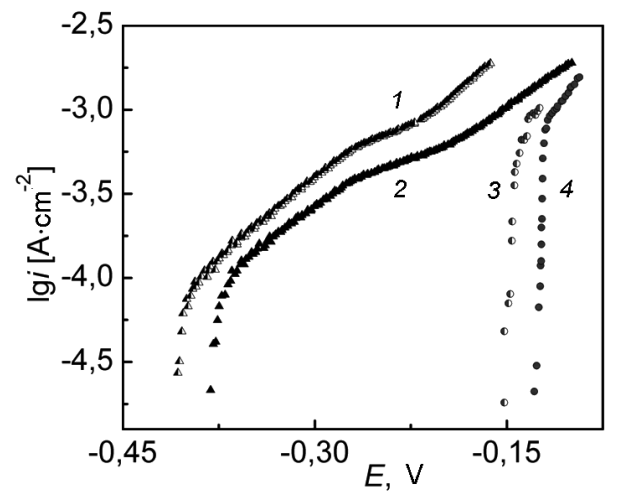

Fig. 5. Anodic polarization dependences for coatings Co-Mo-Zr $(1,2)$ and Co-Mo $(3,4)$ in solutions : $1 \mathrm{M} \mathrm{Na}_{2} \mathrm{SO}_{4}$ with pH $11(1,3)$;

of passive oxides of molybdenum and zirconium which reacting with hydroxide ions.

According to the calculated depth corrosion index $k_{h}$ the synthesized binary alloys with molybdenum content not less than 10 at. $\%$ and the ternary ones with zirconium content of at least 2 at. $\%$ belong to group 1 - "very proof", and can be recommended as protective or barrier coatings for aggressive environments.

Results of testing of the catalytic activity of the Mo-Co and Co-Mo-Zr alloy coatings in the model reaction of hydrogen evolution from different media (Table 2) indicate the synergistic nature of the electrolytic alloys. The exchange current density of hydrogen on the surface of the binary and ternary alloys is higher than this parameter on the alloying components which can be attributed obviously with change in the process mechanism. From the literature [14] it is known that the hydrogen evolution on cobalt occurs by the Volmer-Heyrovsky mechanism $(b=-0.1 \mathrm{~V})$ 
Table 2. Hydrogen current exchange density $\lg i_{\mathrm{H}}^{0}$ and coefficient $b \lg i_{\mathrm{H}}^{0}$ for different materials in acidic and alkali media

\begin{tabular}{|c|c|c|c|c|}
\hline \multirow{2}{*}{$\begin{array}{c}\text { Material } \\
\text { composition, at } \%\end{array}$} & \multicolumn{4}{|c||}{ Medium } \\
\cline { 2 - 5 } & $-\lg i_{\mathrm{H}}^{0}\left[\mathrm{~A} \cdot \mathrm{cm}^{-2}\right]$ & $-b, \mathrm{~V}$ & $-\lg i_{\mathrm{H}}^{0}\left[\mathrm{~A} \cdot \mathrm{cm}^{-2}\right]$ & $-b, \mathrm{~V}$ \\
\hline Pt-100 & 3.30 & 0.03 & 3.10 & 00.100 \\
Co-100 & 4.35 & 0.14 & 4.30 & 0.14 \\
Mo-100 & 8.25 & 0.08 & 4.80 & 0.14 \\
Co-76, Mo-24 & 4.1 & 0.03 & 4.2 & 0.10 \\
Co-75, Mo-22, Zr-3 & 4.0 & 0.1 & 3.9 & 0.03 \\
\hline
\end{tabular}

with the limiting discharge stage (Volmer), which is described for the acidic medium by reaction

$$
\mathrm{H}_{3} \mathrm{O}^{+}+e=\mathrm{H}_{\mathrm{ad}}+\mathrm{H}_{2} \mathrm{O} \text {, }
$$

and for the neutral and alkaline ones

$$
\mathrm{H}_{2} \mathrm{O}+e=\mathrm{H}_{\mathrm{ad}}+\mathrm{OH}^{-} \text {. }
$$

Reducing of hydrogen on the metals subgroups of molybdenum and titanium is described by the same sequence of steps. However, the limiting stage is electrochemical desorption (the Heyrovsky step) occurring in the acid medium by reaction

$$
\mathrm{H}_{3} \mathrm{O}^{+}+\mathrm{H}_{\mathrm{ad}}+e=\mathrm{H}_{2}+\mathrm{H}_{2} \mathrm{O}
$$

and in the neutral and alkaline

$$
\mathrm{H}_{2} \mathrm{O}+\mathrm{H}_{\mathrm{ad}}+e=\mathrm{H}_{2}+\mathrm{OH}^{-} \text {. }
$$

As seen from the coefficient $b=0.03$ (Table 2) the hydrogen evolution both on the electrolytic Co-Mo alloy in the acidic medium and on the Co-Mo-Zr coating in the alkali medium are limited by recombination stage

$$
\mathrm{H}_{\mathrm{ad}}+\mathrm{H}_{\mathrm{ad}}=\mathrm{H}_{2}
$$

i.e. flows through the Tafel mechanism. The same mechanism is typical for platinum, this is evidence of the high catalytic activity of the materials studied.

Thus, combination of metals with different limiting stage of the hydrogen evolution in the active layer allows obtaining the material with catalytic activity close to platinum metals.

Because the binary and ternary alloys include elements exhibiting different activity in the oxidation reaction and having different affinity for oxygen [11], testing the catalytic properties of the Co-Mo and Co-

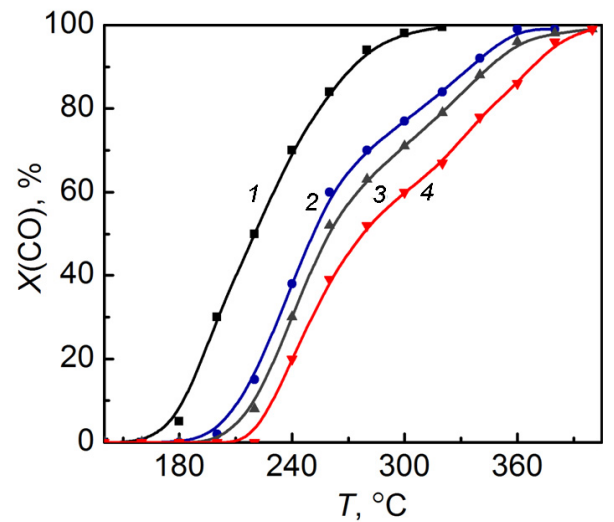

Fig. 6. Thermograms of $\mathrm{CO}$ oxidation on $\mathrm{Pt}$ (1) and electrolytic alloys Co-Mo- $\mathrm{Zr}$ of composition, at. $\%$ : Co $-80.0, \mathrm{Mo}-17.6, \mathrm{Zr}-$ 2.4 (2); Co -81.0 , Mo $-17.5, \mathrm{Zr}-1.5$ (3); Co -82.5 , Mo $-16.8, \mathrm{Zr}-0.7$ (4).

Mo- $\mathrm{Zr}$ coatings in the model reaction of $\mathrm{CO}$ oxidation to $\mathrm{CO}_{2}$ is of great interest. As can be seen from Fig. 6, the thermograms of carbon oxide (II) oxidation on the surface of catalyst coated with the ternary alloys with various content of zirconium have two sections with different slopes.

In the first plot within the temperature interval of $200-270^{\circ} \mathrm{C}$ the kinetics of $\mathrm{CO}$ oxidation is not differ from the platinum plate catalyst with $c \omega(\mathrm{Pt})=100$ at $\%$ although both the reaction initiation temperature $T_{i n}$ as well as temperature of $50 \%$ conversion are higher than for platinum by $40-50^{\circ} \mathrm{C}$ (Table 3). In the second plot at the temperature above $270^{\circ} \mathrm{C}$ the oxidation rate declines probably due to formation of the alloying metals oxides on the surface. The conversion degree rises by the average of $7-10 \%$ with increase of the zirconium content in the coating by 1 at $\%$ but the influence of zirconium weakens at the temperatures higher than $350^{\circ} \mathrm{C}$. Evidence of the high catalytic activity of materials is the 
Table 3. Parameters of $\mathrm{CO}$ oxidation model reaction on different catalytic materials

\begin{tabular}{|c|c|c|c||}
\hline $\begin{array}{c}\text { Catalyst composition, } \\
\text { at \% }\end{array}$ & $\begin{array}{c}\text { Ignition temperature } T_{i}, \\
{ }^{\circ} \mathrm{C}\end{array}$ & $\begin{array}{c}\text { Temperature } \\
\text { for } 50 \% \text { conversion }\end{array}$ & $\begin{array}{c}\text { Temperature } \\
\text { for 99\% conversion }\end{array}$ \\
\hline $\mathrm{Pt}_{100}$ & 190 & 220 & 250 \\
$\mathrm{Co}_{80} \mathrm{Mo}_{17.6} \mathrm{Zr}_{2.4}$ & 230 & 260 & 370 \\
$\mathrm{Co}_{81} \mathrm{Mo}_{17.5} \mathrm{Zr}_{1.5}$ & 240 & 270 & 375 \\
$\mathrm{Co}_{82.5} \mathrm{Mo}_{16.8} \mathrm{Zr}_{0.7}$ & 230 & 280 & 400 \\
\hline
\end{tabular}

fact that $99 \%$ conversion is achieved at the temperatures of $375-380^{\circ} \mathrm{C}$.

The catalytic properties of the synthesized systems are caused by presence of cobalt forming nonstoichiometric oxides with different thermal resistance as well as by the high affinity for oxygen of molybdenum and especially zirconium.

Thus, based on the results obtained the electrolytic coating of Co-Mo- $\mathrm{Zr}$ with $\mathrm{Zr}$ content higher than 1.5 at. \% can be recommended as effective catalytic material for oxidation reactions instead of expensive platinum catalysts.

\section{Conclusions}

Binary and ternary alloys of cobalt with molybdenum (zirconium) of different composition and morphology are obtained from polyligand citrate-pyrophosphate electrolyte using the pulsed mode by varying the current density and temperature. It is shown that at the current density of not more than $3 \mathrm{~A} \cdot \mathrm{dm}^{-2}$ the coatings with micro-globular topography without stress and cracks are formed. The electrolytic alloys are solid solutions of zirconium and tungsten in cobalt in the wide range of alloying metals concentrations.

Chemical resistance of the binary and ternary coatings based on cobalt is caused by the increased tendency to passivity and high resistance to pitting corrosion in the presence of molybdenum and zirconium, as well as the acid nature of their oxides. The binary coating with molybdenum content not less than 10 at. $\%$ and the ternary ones with zirconium content in terms of corrosion deep index are in the group of "very proof" and can be recommended as protective for corrosive environments.

The electrolytic Co-Mo and Co-Mo-Zr alloys demonstrated synergism of catalytic activity for the hydrogen reduction from various media. It is shown that the combination of the metals with different limiting stage of the hydrogen evolution allows the obtaining a material with the catalytic activity close to platinum metals.

4. The electrolytic alloy Co-Mo-Zr with a $\mathrm{Zr}$ content of not less than 1.5 at $\%$ exhibits the catalytic activity in the oxidation of carbon (II) oxide. This allows you to recommend the synthesized materials to replace platinum catalysts for improving the efficiency of the combustion of hydrocarbons and purification of gas emissions from toxic substances.

\section{References}

1. S.Endres, P.Kampe, J.Kunert et al., Appl. Catalys. A: General, 325, 2 (2007).

2. M.K.Stoyanova, S.G.Christoskova, Central Eur. J. Chem., 3, 2 (2005).

3. S.Nagashima, K.Kudo, H.Yamazaki et al., Appl. Catalys. A: General, 450 (2013)

4. S.V.Kolotilov, K.S.Gavrilenko, M.R.Kantserova et al., Theor. Exp. Chem., 41, 6 (2005).

5. V.S.Kublanovsky, Yu.S.Yapontseva, Electrocatalysis, 5, 5 (2014).

6. M.Glushkova, T.Bairachna, M.Ved, M.Sakhnenko, MRS Proc., 2013. doi:10.1557/opl.2012.1672.

7. M.V.Ved', T.O.Nenastina, T.M.Bairachna, M.D.Sakhnenko, Materials Science, 44, 4 (2008).

8. M.V.Ved, N.D.Sahnenko, M.A.Glushkova et al., Voprosy Khimii i Khimicheskoy Tekhnologii, 5, 5 (2015).

9. N.D.Sakhnenko, P.A.Kapustenko, M.V.Ved', S.G.Zhelavskii, Prot. Metals, 34, 4 (1998).

10. M.O.Glushkova, M.V.Ved', M.D.Sakhnenko, Mat. Sci., 49, 3 (2013).

11. M.Ved', M.Glushkova, N.Sakhnenko, Functional Materials, 20, 1 (2013).

12. N.Tsyntsaru, A.Dikusar, H.Cesiulis et al., Powder Metal. Metal Ceram., 48, 7 (2009).

13. E.J.Podlaha, J.. Electrochem.Soc., 144, 5 (1997).

14. F.N.Frumkin, Hydrogen Overpotential, Nauka, Moscow (1988) [in Russain]. 